症例

FDG-PET CT にて遠隔リンパ節転移が疑われた小型肺腺癌の 1 例

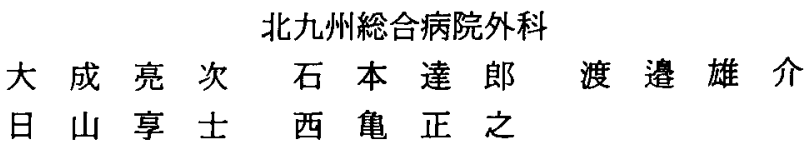

症例は70歳, 男性. 嗄声を主訴に近医耳鼻科を受診し, 左反回神経麻瘏と診断された。 精查加療目的で当院を紹介され受診した. 頭頸部の視触診ならびに頸部超音波検査, 上 部消化管内視鏡検查では異常なかった. 胸部 CT で右肺 $\mathrm{S} 4 \mathrm{~b} に 1.1 \times 1.0 \mathrm{~cm}$ 大の結節影 を認めたが、肺門および綎隔リンパ節の有意な腫大はなかった，頸部 CT で気管に接し て0.8cm 大の結節影を 2 個認めた. FDG-PET CT て肺および頸部の結節影に一致して 異常集積を認めたため, いずれも生検の適応と判断した. 肺結節はVATS 肺生検で乳頭 状腺癌と診断されたため, 右肺中葉切除 (ND2a) 施行したが, 肺門および䋛隔リンパ節 に転移はなかった. 2 個の頸部腫瘤は生検でいずれも肺癌のリンパ節転移と診断された. FDG-PET CT は結節性病変の質的診断においてだけでなく, 遠隔リンパ節転移の同定 という局在診断においても有用であった。

真引用語：FDG-PET CT, 遠隔リンパ節転移, 肺腺癌

\section{緒言}

FDG-PET CT は肺癌の診断において, 原発巣やリ ンパ節の良悪性の質的診断や進行度評価に有用な非侵 襲的検查とされる。

今回われわれは，FDG-PET CT にて遠隔リンパ節 転移が疑われた小型肺腺癌の 1 例を経験したので報告 する。

症例

患者: 70歳, 男性.

既往歴：平成10年に肺炎.

家族歴：特記事項なし。

喫煙歴：15本/日 50 年間.

職業歴: 理容師。

現病歴：2 年前から嗄声を自覚していたが，平成 17 年 9 月から悪化したため11月に近医の耳鼻科を受診し た. 左反回神経麻疸を指摘され，当院に紹介された。 頸胸部 CTで右肺に 1 個と頸部に 2 個の結節影を認 め, 精査加療を目的に入院となった。

理学所見: 身長 $167 \mathrm{~cm}$, 体重 $60 \mathrm{~kg}$. 意識清明. 体重

2006年 5 月31日受付 2006年 6 月21日採用

〈所属施設住所〉

厂800-0295 北九州市小會南区湯川 5-10-10
減少なし. 体温 $36.8^{\circ} \mathrm{C}$, 脈拍 $86 / \mathrm{min}$, 呼吸数 $18 / \mathrm{min}$, 血圧 $110 / 78 \mathrm{mmHg}$. 心音は整で雑音なし。呼吸音は正 常,ラ音を聴取しなかった。頸部に腫瘤を触れなかっ た。

血液生化学検查：CEA が4.3(0 3.2) ng/ml と上 昇していたが, その他の検査に異常はなかった。

肺機能検查：異常は認めなかった。

胸部 X 線所見：右下肺野に境界明膫な $1 \mathrm{~cm}$ 大の結 節影を認めた。

頚部 CT 所見：鎖骨上の気管前面と気管左壁に接し て径 $0.8 \mathrm{~cm}$ の結節影を 2 個認め, 左反回神経麻疸の原 因病巣として気管左壁に接する腫瘤が疑われた（図 1 ).

胸部 CT 所見：右肺 S4b の部位に中下葉間に接し て $1.1 \times 1.0 \mathrm{~cm}$ の境界明瞭で分葉状の結節影を認めた

(図 2 a ).肺門および綎隔リンパ節の腫大はなかった (図 2 b).

喀痰細胞診：異常は認めなかった。

喉頭内視鏡検査：左声帯麻疸を認めたが，喉咽頭に 腫瘍性病変はなかった。

上部消化管内視鏡検查：異常はなかった.

頚部超音波検査：2 個の頸部腫瘤は同定できず, 甲 状腺に異常はなかった。 
FDG-PET CT：FDG の異常集積を 3 カ所に認め た. 右中葉の腫瘤に一致して遅延像で増加を示す異常 集積 $(\mathrm{SUVe}=2.12, \mathrm{SUVd}=2.95 ）$ を認めた．2個の

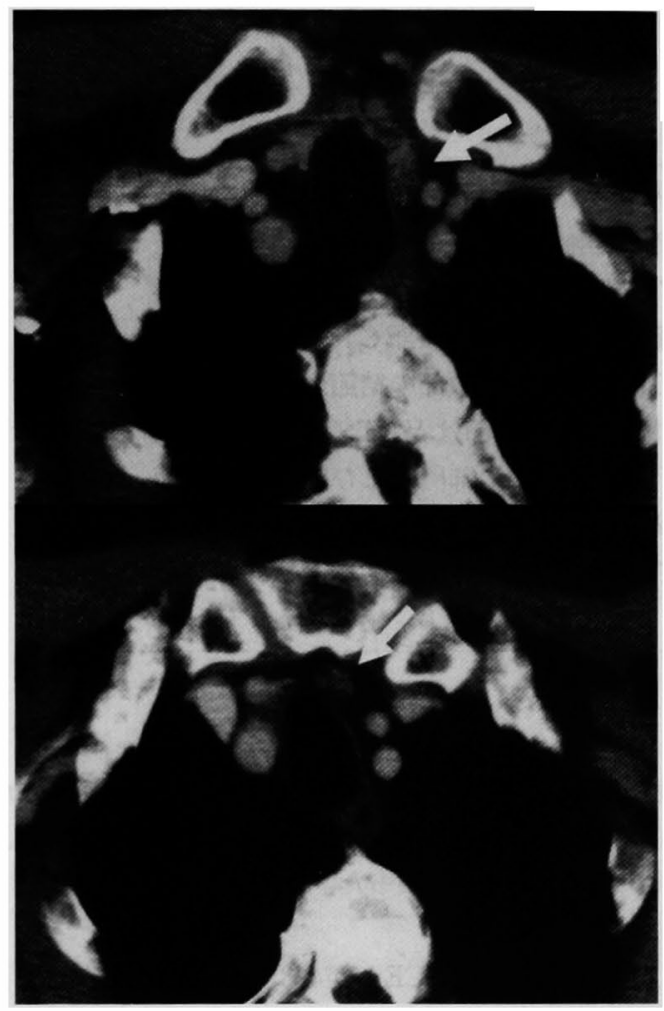

図 1 頸部 CT 検查：頸部の気管前面と気管左壁に 接して径 $0.8 \mathrm{~cm}$ の結節影を 2 個認めた。
頸部腫瘤に一致して遅延像で増加を示す異常集積（気 管前面: $\mathrm{SUVe}=3.22, \mathrm{SUVd}=4.27$, 気管左壁: $\mathrm{SUVe}=2.95, \mathrm{SUVd}=4.26$ ) を認めた（図 3 ).

FDG-PET CT で異常集積を示した 3 力所の病変 は, 組織生検の適応と判断し手術を施行した。

\section{手術所見：}

(1) 肺腫痹（平成17年11月）

VATS 生検で腫瘤と接していた下葉の一部も含め て楔状切除を行った。迅速病理猃断で乳頭状腺癌と診 断され，中葉切除術 (ND2a) を施行した。迅速病理診 断では\#11s と\#12mに転移はなかった。

(2) 頸部腫瘤 (平成17年12月)

全身麻酔下に 2 個の頸部腫瘤を生検した。気管左壁 の腫瘤は左反回神経を巻き込んでいた，迅速病理で腺 癌のリンパ節転移と診断されたが, 線維化を伴う強い 瘕痕形成のため病理学的に肺癌の転移と診断できなか った。甲状腺は慢性の炎症性変化があり, 弾性硬で腺 内の腫瘤の有無を触診で判断できなかった，気管左壁 の腫瘤は左葉下極に強く癒着していたうえ, どちらも 甲状腺癌の頸部りンパ節転移として矛盾ない部位にあ った。甲状腺の触知不能癌の可能性も否定できず，や むなく左葉切除術および頸部りンパ節郭清を施行し た.

\section{病理組織所見：}

\section{(1) 肺腫湯}

腫瘍は $1.1 \times 1.0 \times 1.0 \mathrm{~cm}$ 大で充実性，境界明膫，弾 性軟であった．組織学的には腫湯細胞は異型が強く核 内封入体様構造が散見された．腫瘍性の線維性血管間

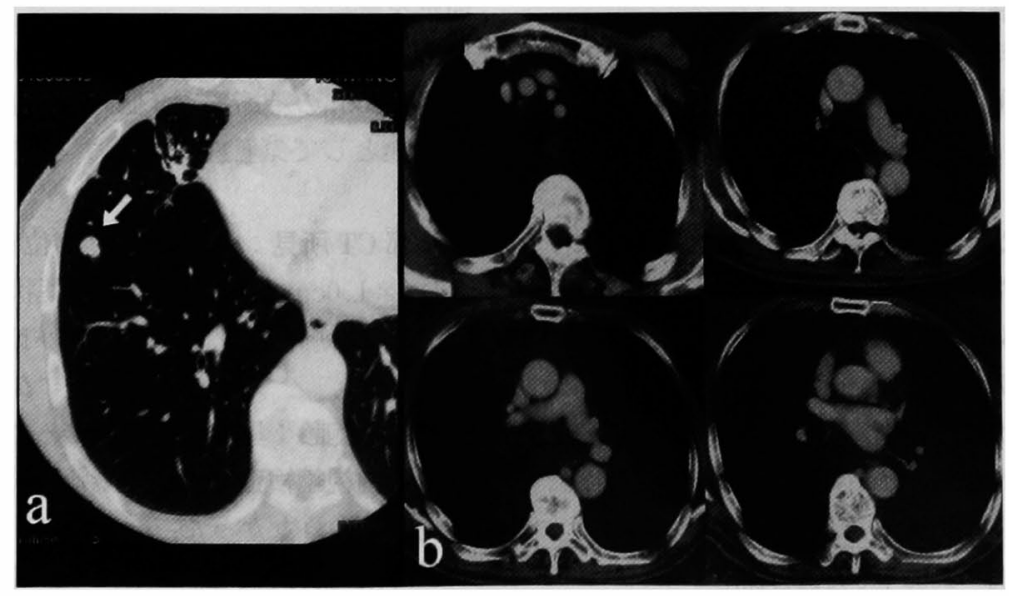

図 2 胸部 CT 検査：右 $\mathrm{S} 4 \mathrm{~b}$ に中下葉間に接して $1.1 \times 1.0 \mathrm{~cm}$ 大の境界明瞭で分 葉状の結節影を認めたが，肺門わよび縦隔リンパ節の腫大はなかった。 


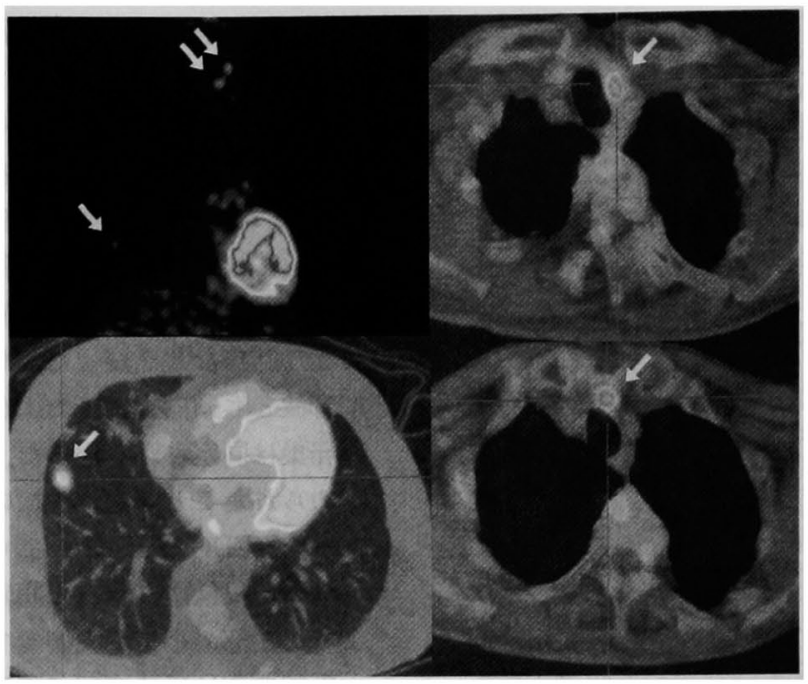

図 3 FDG-PET CT 検査：右中葉の腫瘤と 2 個の頸部腫瘤に一 致して FDGの異常集積を認めた.

質を有し，肺胞構造を破壊しつつ肺実質に浸潤性の不 規則な乳頭状増殖を呈しており，野口分類 $\mathrm{F}$ 型の乳頭 状腺癌と診断した (図 $4 \mathrm{a}$ ). 免疫組織染色では CEA, CA19-9, p53, c-erb-B2が陽性で, SPA は一部で陽性 を示した。

\section{(2) 頸部腫瘤}

頸部腫瘤はいずれも線維性の瘕痕形成を認めた。組 織学的にはリンパ節の構造の内部に低分化な乳頭状腺 癌を認め, 脱分化した肺腺癌のリンパ節転移と診断し た (図 4 b).

最終診断は頚部リンパ節転移を有する右肺中葉の進 行肺腺癌 (pt1n3M0, Stage III B) で, FDG-PET CT の有用性が組織学的に確認された. 化学療法の適応と し2006年 1 月より開始した. 術後 6 カ月が経過したが 再発を認めていない。

\section{考察}

原発性非小細胞肺癌の中でも腺癌は, 腫瘍径が小き くても比較的早期からリンパ節転移を起こしやすいと

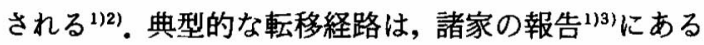
ように肺内もしくは肺門リンパ節を介するもので, 縦 隔から頸部へ進展することが多い，中葉原発の肺癌の 場合, 肺内リンパ節から(1)\#10および\#7を介して対 側を含めた上縦隔へと続き，また，(2)\#10および\# 3 を介して気管右側を\#1へと続く流路である.肺門り ンパ節をセンチネルリンパ節として位置づける考えか ら, ラジオアイソトープ法で肺門リンパ節転移がない
場合, 縦隔郭清の省略を検討されうるとの報告(4)あ り，緃隔リンパ節転移の有無を推測するうえで, 肺門 リンパ節の転移の有無を検索することは意義がある. また，成毛らりによると綐隔リンパ節転移をきたした 中葉原発の肺癌を検討した結果, 肺門の は\#11s，\#11i などのリンパ節に転移することが多い 一方で，\#7 を含む下縦隔リンパ節および３ 3 を含ん だ上縦隔リンパ節にも高頻度の転移を認めたという。 すなわち, 中葉原発の肺癌は, 頸部までリンパ節転移 が拡がっている場合, 肺門もしくは緹隔リンパ節に転 移をきたしている可能性が高いと考えられる，原発性 非小細胞肺癌のなかでも腺癌は, 縌隔リンパ節にスキ ップ転移を起こす頻度が高い"が，本症例のように頸 部にのみ転移をきたしている例は稀と思われる，以上 の理由から, 頸部病変は FDG-PET CT では頸部リン パ節への転移を示唆していたにもかかわらず，積極的 にこれを疑えなかったため生検の適応とした。

縦隔リンパ節転移の衍前診断には, 縦隔鏡, CT, PET など行われる. 縦隔鏡は最も正診率が高いが侵襲 が大きく，また， リングできない部位があることが欠点である ${ }^{5)}$. CT と PET は, 単独または併用でその診断能が比較検討され た報告が多(の)ー8). CT では最小腫瘤径が $1 \mathrm{~cm}$ を超え るものを陽性として検討されることが一般的であ

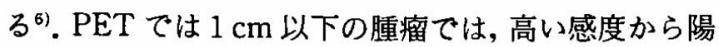
性を示す例があるものの，偽陽性や偽陰性を示す例も 


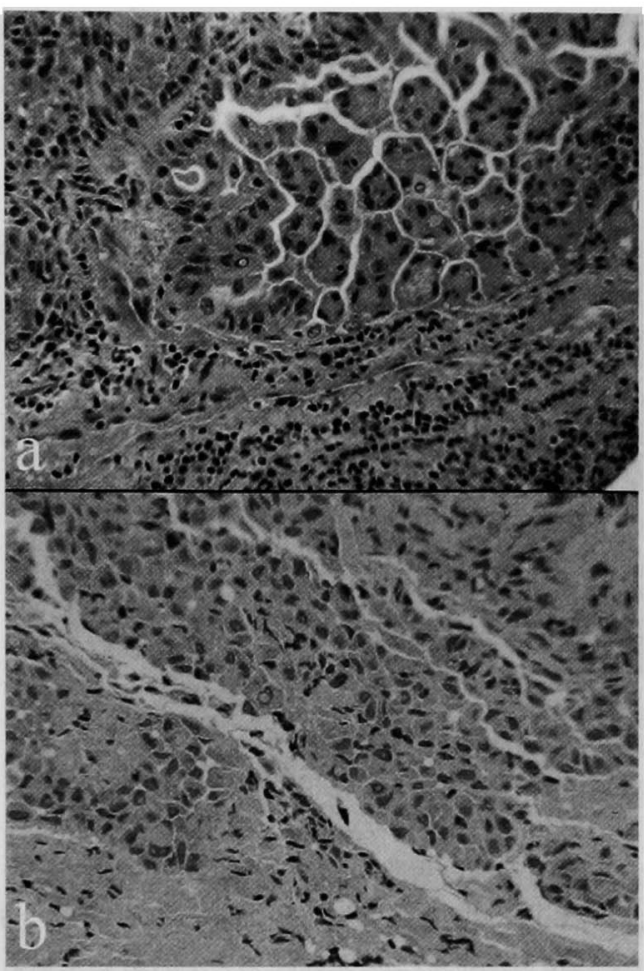

図 4 病理組織所見 $(\mathrm{HE}$ 染色, $\times 160) ： a)$ : 肺腫瘍 は細胞異型が強く, 肺胞構造を破壊しつつ肺実質 に浸潤性に不規則な乳頭状增殖を呈しており，野 口分類 $\mathrm{F}$ 型の乳頭状腺癌と診断された. $\mathrm{b}$ )頸部腫 瘤はリンパ節の構造が遺残し，内部に低分化な乳 頭状腺癌が翟められ，脱分化した肺腺癌のリンパ 節転移と診断された。

多く，一般的に $1 \mathrm{~cm}$ 以下の腫瘤では正確な評価が行 えないとされる゙。本症例の頸部病変はいずれも最大 径が $0.8 \mathrm{~cm}$ で正確に評価できなかった。

VATS 生検を先行させた理由は, 帽病変が悪性と診 断され、綎隔リンパ節に病理学的に転移が認められた 場合は，頸部病変もこれに続くリンパ節転移と考えら れるため, 頸部の生検を省略できると考えたためであ る.しかし，郭清した縦隔のリンパ節に転移がなかっ たため, 頸部病変の生検が必要となった. 繸隔鏡を先 行させたとしても，頸部腫瘤はいずれも疫痕形成が著 明で周囲と強く癒着していたため，手技的に生検は困 難であった。

肺病変は反回神経麻疩の対側にあるうえ，腫瘍径が 小さく, CT 画像上は悪性を積極的に示唆する所見に そしく，肺門・縦隔に明らかなリンパ節腫大がなかっ た。しかし，頸部病変は臨床的に悪性を強く疑われる
ため, 頸部病変と肺病変の組織像を比較する必要があ りVATS 生検の適応としたが，その最大の根拠は FDG-PET CT で異常集積を示したことである.

頸部病変はその局在から左反回神経麻疩の原因と推 測され，臨床的には悪性腫湯を強く疑った，原発性腫 瘍としては悪性リンパ腫や甲状腺癌を，リンパ節への 転移性腫瘍としては甲状腺癌, 咽頭・喉頭癌, 食道癌, および肺癌などを疑った。しかし，頭頸部精查（頸部 超音波と喉頭内視鏡）および上部消化管内視鏡検査で 原発巣は同定されなかった. FDG-PET の異常集積が 認められたことが組織生検の適応とした重要な根拠で あった. FDG-PET CT は, 従来の FDG-PET に比へ て正確に異常集積部位の同定が可能であり，本症例の ような頸部の小結節性病変でも有用であった。

頸部病変は迅速病理で腺癌と診断されたが, 瘦痕形 成が著明で脱分化していたため病理学的に原発巣の同 定にいたらなかった，さらに甲状腺の触知不能癌の可 能性も否定できなかったため, やむなく甲状腺左葉切 除術および頸部リンパ節郭清を施行した。最終的な病 理組織診断で甲状腺に腫瘍はなく，両病変は肺癌のリ ンパ節転移と診断された。

本症例は FDG-PET CT で中葉の原発性肺癌と頸 部リンパ節転移を疑われたが，上述の理由で手術を施 行した。その結果, 病理学的に手術適応外の進行肺腺 癌と診断され，リンパ節転移診断における FDG-PET CT の高い感受性と信頼性が示された。本症例では VATS 生検で肺癌と診断された時点で, FDG-PET CT の結果に従って化学療法を開始するべきであっ た、リンパ節転移診断において FDG-PET CT の有用 性が示され，今後同様の症例では，診断を目的とした 肺葉切除と繸隔郭清ならびに頸部リンパ節生検が省略 できる可能性が示唆された。

\section{結 語}

左反回神経麻痹を呈する中葉の小型肺腫瘤と頸部腫 瘤に対し, 縋隔郭清を伴う中葉切除術と甲状腺左葉切 除および頸部りンパ節郭清術を行った。良悪性の質的 診断ならびに原因病巣の局在診断における FDGPET CT の有用性が，病理組織学的に確認された。

謝辞

病理診断にご協力いただいた北九州総合病院臨床検査 科・研究部貝藤隼人先生に深謝致します。

\section{文献}

1) Naruke $T$, Tsuchiya $R$, Kondo $H$, et al : Lymph node sampling in lung cancer : how should it be 
done? Euro J Cardiothorac surg 16 (suppl 1) : S17-S24, 1999

2）坪田紀明, 吉村雅裕, 室谷陽裕他：原発性肺癌に おけるリンパ節の転移様式 合理的なリンパ節郭 清. 日呼外会誌 $9: 122-128,1995$

3) Asamura $H$, Nakayama $H$, Kondo $H$, et al : Lobe-specific extent of systematic lymph node dissection for non-small cell lung carcinomas according to a retrospective study of metastasis and prognosis. J Thorac Cardiovasc Surg 117 : 1102-1111, 1999

4) Liptay MJ, Masters GA, Winchester DJ, et al : Intraoperative Radioisotope Sentinel Lymph Node Mapping in non-small cell lung cancer. Ann Thorac Surg $70: 384-390,2000$

5) De Leyn P, Vansteenkiste J, Cuypers $P$, et al : Role of cervical mediastinoscopy in staging of non-small cell lung cancer without enlarged mediastinal lymph nodes on CT scan. Eur J Cardiothorac Surg $12: 706-712,1997$

6) Webb WR, Gatosonis C, Zerhouni EA, et al: $\mathrm{CT}$ and MR imaging in staging non-small cell bronchogenic carcinoma: report of the Radiologic Diagnostic Oncolory Group. Radiology 178: 705-713, 1991

7) Pieterman RM, van Putten JW, Meuzelaar JJ, et al: Preoperative staging of non-small cell lung cancer with positron-emission tomography. N Engl J Med 343:254-261, 2000

8) Takamochi K, Nagai K, Yoshida J, et al : The role of computed tomographic scanning in diagnosing mediastinal node involvement in non-small cell lung cancer. J Thorac Cardiovasc Surg $119: 1135-1140,2000$

\title{
A CASE OF SMALL ADENOCARCINOMA OF THE LUNG WITH DISTANT NODAL METASTASES SUGGESTED BY FDG-PET CT
}

\author{
Ryoji ONARI, Tatsuro ISHIMOTO, Yusuke WATANABE, \\ Takashi HIYAMA and Masayuki NISHIKI \\ Department of Surgery, Kitakyushu General Hospital
}

A 70-year-old man complaining of hoarseness diagnosed as having left recurrent nerve paralysis by anotolaryngologist was referred to our hospital for further examination and treatment.

There were no abnormal findings on physical examination of the head and neck region, cervical ultrasonography and gastrointestinal fiberscopy. Chest CT scan showed a $1.1 \times 1.0 \mathrm{~cm}$ nodular shadow in the left segment $4 \mathrm{~b}$ of the lung, but enlarged hilar and mediastinal lymph nodes were absent. Cervical CT scan showed two small nodules $0.8 \mathrm{~cm}$ in diameter which were adjacent to the trachea. Surgical extirpations were indicated for all lesions because of high accumulation on FDG-PET CT. A wedge resection of the middle lobe of lung was performed by VATS, and the pulmonary nodule was diagnosed as papillary adenocarcinoma by the frozen section. A middle lobectomy with systematic nodal dissection (ND2a) was done. Pathological examination revealed no hilar and mediastinal lymph node metastases of adenocarcinoma. The pathological diagnoses of two cervical nodules after the extirpation were metastatic lymph nodes of adenocarcinoma of the lung. FDG-PET CT was useful not only for making biological diagnosis of the pulmonary nodular shadow, but also for identifying distant nodal metastases of adenocarcinoma of lung in this patient. 